European journal of American studies

\title{
Spectacular Bodies: Los Angeles Beach Cultures and the Making of the "California Look" (1900s-1960s)
}

\section{Elsa Devienne}

\section{(2) OpenEdition}

\section{Journals}

Electronic version

URL: https://journals.openedition.org/ejas/15480

DOI: $10.4000 /$ ejas. 15480

ISSN: 1991-9336

Publisher

European Association for American Studies

Electronic reference

Elsa Devienne, "Spectacular Bodies: Los Angeles Beach Cultures and the Making of the "California Look" (1900s-1960s)", European journal of American studies [Online], 14-4 | 2019, Online since 23

December 2019, connection on 07 December 2022. URL: http://journals.openedition.org/ejas/15480 DOI: https://doi.org/10.4000/ejas.15480

This text was automatically generated on 8 July 2021.

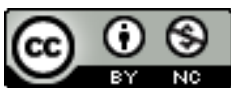

Creative Commons - Attribution-NonCommercial 4.0 International - CC BY-NC 4.0 https://creativecommons.org/licenses/by-nc/4.0/ 


\title{
Spectacular Bodies: Los Angeles Beach Cultures and the Making of the "California Look" (1900s-1960s)
}

\author{
Elsa Devienne
}

1 In 1951, Life magazine ran a photo essay celebrating the vitality of West Coast youth. Among the many pictures of young Californians portrayed sailing, skiing, horse-riding, and surfing, one photograph stood out. Set in Santa Monica's famous "Muscle Beach" playground, it pictured five bodybuilders wearing tight briefs and showing off their bulging biceps. Despite their obvious efforts to look good, the five men were mocked in the accompanying text for "carrying the body cult from the sublime to the absurd." Clearly, the Life magazine journalists were unimpressed by such a display. As was Charles Flynn, a reader from Pawtucket, Rhode Island, who felt compelled to send a photograph, printed in the next issue's Letters to the Editor, to "show... West Coasters how the east coast youth enjoy themselves at the beach." ${ }^{1}$ In stark contrast to the tanned and brawny Muscle Beach athletes, the reader's black and white snapshot represented eight men of medium build-one of them with a visible paunch protruding from his T-shirt-lounging lazily on the beach while drinking cans of beer. No doubt in this reader's mind this was a far more relaxing way to spend an afternoon at the beach. The two photographs highlighted the precarious status of the muscular body during the 1950s, when it had yet to become a marker of respectability and sexual appeal for middle-class heterosexual men. ${ }^{2}$ More importantly, this juxtaposition threw the widening distance, both physical and metaphorical, between Southern California and East Coast beach bodies in sharp relief. On the East Coast, the beach experience was associated with idleness and relaxation. In contrast to the strict discipline that regulated bodies at the office and in the factory, going to the beach meant freeing one's body from social prescriptions and sartorial rules. On the West Coast, however, going to the shore was a serious affair, requiring bodies to be appropriately groomed and clothed. On Southern California beaches in particular, bodies had to be prepared for public display. 
2 By the 1950s, a distinct Southern California beach culture celebrating the display of beautiful bodies had taken shape and occupied a prominent place within American visual imagery. Centered on the iconic figures of the bathing beauty, the bodybuilder, and the surfer, it emphasized physical fitness, sensuality, and showmanship. Scholars and journalists have long identified what author Carey McWilliams called the Southern California "cult of the body"-the historical emphasis placed by the region's residents on physical health, fitness, and beauty. ${ }^{3}$ In the 1930s, Los Angeles journalist Farnsworth Crowder claimed that this special relationship between Californians and their bodies was "dictated by the sun." ${ }^{4}$ In other words, Californians' love affair with exercise was linked to the region's year-round warm weather. While climate and geography certainly afforded ideal conditions for Californians to exercise outdoors, these factors cannot fully account for their exceptional interest in physical beauty and public performance-two essential dimensions of the region's unique strand of "bodyawareness." ${ }^{5}$ Over the years, however, many scholars have stood by this explanation. Kevin Starr, in his multi-volume history of California, claimed that Crowder's thesis was "overstated" but ultimately "correct." ${ }^{\prime}$ Historians interested in the rise of the fitness revolution have highlighted the prominent role played by Southern Californian gym entrepreneurs, film stars, and athletes in convincing Americans to exercise, but they often fail to locate their trajectories within the larger social history of the region. ${ }^{7}$ In fact, scholars generally approach the topic of Southern California's special relationship with beautiful bodies from the perspective of the history of representations. Kirse Granat May, for instance, used films and television shows to trace the rise of the sun-tanned California teen as a popular culture icon in the postwar era, while Claudia Bohn-Spector relied on photographs to identify Southern California's "lustful corporeality."

3 Although useful, these studies do not say a great deal about the actual spaces in which such spectacular bodies were shaped and displayed, nor do they situate them within the region's broader social history. In addition, they say little about the origins of the Southern California beach culture before it reached an international audience in the postwar period, due to the surfing boom. In contrast, in this article I consider Los Angeles' beaches as sites of spectacles in which a unique brand of corporeal culture centered on the display of beautiful physiques originated. Unlike in Europe and the East Coast, where hygienist justifications for seaside recreation endured, from the early twentieth century onwards Southern California beachgoers set medical concerns aside and focused on having fun and parading their bodies. Such a brazen and hedonistic engagement with the coastline, I argue, was the result of Los Angeles' unique characteristics as a horizontal, low-density, and car-centric city with an economy dominated by tourism and by Hollywood and its attendant industries, particularly health and fitness. The popularity of Los Angeles's beach cultures, I argue, eventually led to the creation of the self-styled "California look": bronzed skin, bleached hair, and bulging muscles. ${ }^{9}$ By the 1950 s, this set of body features was, if not universally revered, as the Life reader's letter and photograph attest, easily identifiable by the public. It had become associated with a specific place (the beach) and region (Southern California), and represented both an enviable commodity within the consumer marketplace and a familiar trope within American popular culture. Thanks to Hollywood, the California look traveled far and wide, influencing beauty standards throughout the western world. 
4 Yet the California look obscured as much as it showcased the actual bodies of Angelenos. Despite persistent forms of discrimination on the coastline, Latino, AsianAmerican, and African-American beachgoers consistently engaged with local beach cultures: they won Mister Muscle Beach titles, organized their own bathing beauty parades, and proved on a daily basis that surfing bodies were more racially diverse than those displayed on "surf music" album covers. By taking social practices situated in local settings into account as well as nationally circulated representations of beautiful Southern California bodies, this article will present a more complex appreciation of the origins, "whitewashing," and eventual fetishization of the California look in the twentieth century. ${ }^{10}$

\section{The Making of a Southern California Beach Culture in "Westside LA"}

5 Although its international reputation is inextricably linked to the shoreline, as portrayed in countless films and television shows, Los Angeles is not a traditional coastal city. Its original site, now the city's downtown area, is located near the Los Angeles River, about fifteen miles from the Pacific Ocean. In the second half of the nineteenth century, the beaches of Santa Monica Bay-the closest beaches to downtown-were isolated from the city's main population and economic centers. In the 1890s, attempts at developing a deep-water harbor in Santa Monica and Redondo Beach failed, and industrial and commercial port activities remained confined to the distant San Pedro Bay. ${ }^{11}$ Its striking natural beauty preserved from industrial nuisances, the Santa Monica Bay was nonetheless peripheral to the initial development of tourism in Southern California. As historian Catherine Cocks points out, "the beach was not particular important in early Southland tourism." ${ }^{12}$ Easterners who made the trip out west, many of them on doctors orders, came to enjoy the region's balmy climate and improve their constitution or, more prosaically, escape the harsh New England winters. Dry climate, which was considered ideal to treat tuberculosis, could best be enjoyed inland, and thus Pasadena, not Santa Monica, became the center of a "thriving hotel culture" in the foothills of the San Gabriel Mountains. ${ }^{13}$ In the 1880s, as thousands of invalids and consumptive patients flocked to the region in search of a miraculous cure, contemporaries likened Los Angeles to "one vast sanatarium." ${ }^{14}$

6 Wealthy East coast tourists did make the journey to the ocean-first by horse-drawn buggies and wagons and, starting in the late 1870s, by rail. But the "modern means of appreciating the sea" and the sun had yet to be "invented" and legitimized by science. ${ }^{15}$ The turning point came in the first decade of the twentieth century, when the theories behind the heliotherapy movement gained wider acceptance in the US and Europe, encouraging healthy adults and children, not just invalids, to disrobe and spend time in the sunlight. ${ }^{16}$ In parallel, local businessmen took notice of the growing vogue for seaside recreation and beach bathing across the US. The success of New York's Coney Island hinted at the enormous profits that could accrue from attracting pleasureseekers rather than health-seekers. With the famed Brooklyn amusement area as a key model, businessmen established bathhouses, amusement parks, hotels, and tramway lines along the coast. By the late 1900s, beach resorts such as Venice, Long Beach, and Ocean Park were all claiming the title "Coney Island of the West". ${ }^{17}$ 
But the beaches of Los Angeles soon became rather more than another Coney Island. In the early 1920s, Los Angeles elites made a conscious decision to promote decentralization and a low-density urban landscape..$^{18}$ Developers seized this opportunity to turn the coast into a new node of a polycentric metropolis, producing glossy brochures with the promise of year-round resort living just a stone's throw from the downtown area. Health, which had long sustained Southern California's reputation, remained a major selling point. But the targeted clientele was now already a healthy one. In advertisements for the brand-new coastal neighborhood of Palisades del Rey (now Playa Del Rey), swimsuit-clad blond cherubs happily played in the sand while their parents relaxed in the background in sun loungers. By living by the ocean and only "35 minutes from 7th and Broadway," Southern California parents would ensure their progeny's health and happiness as well as their own. One article in the local newspaper (printed and circulated by the real estate firm behind the new development) even went so far as to claim that the first baby born in Del Rey was of "perfect physical condition," thanks to the "delightful climatic conditions." ${ }^{19}$ Such promotional literature pointed at the gradual shift in the local brand of boosterism, from praising climate as a cure to celebrating local environmental conditions in general as a source of health, beauty, and corporeal pleasures.

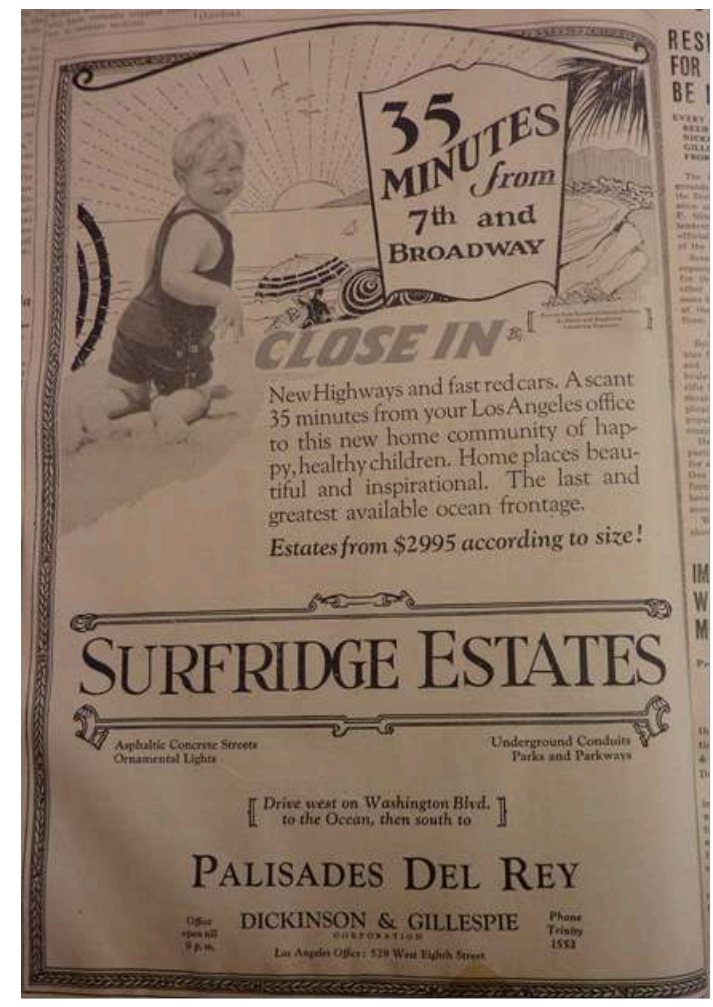

Figure 1. Advertisement for the Surfridge Estates in Palisades Del Rey, 1926. Palisades Del Rey Press, May 15, 1926, 8. Box 8ov, Fritz Burn Papers. Department of Archives and Special Collections, William H. Hannon Library, Loyola Marymount University, Los Angeles, California.

The strategy worked: in the 1920s, just as the Los Angeles county population was doubling in size to reach over 2.2 million inhabitants by 1930, thousands of new residents settled on the coast, turning the small beach resorts of the early twentieth century into full-fledged residential communities. In Reyner Banham's account of the rise of "surfurbia," the term he coined to describe the coastal landscape of 
metropolitan Los Angeles, there is no clearer sign of this shift than the fact that, by 1925, Santa Monica had "more pianos than any other cities its size in the County."20 This movement of population towards the Pacific eventually created what Angelenos have come to call the "Westside," an ensemble of coastal municipalities and neighborhoods characterized by their proximity to the ocean, where residents could partake in a hybrid lifestyle, halfway between suburbia and resort life. If, as Lawrence Culver argues, Los Angeles was marketed to the rest of the nation as a "city of leisure," then the Westside was where marketing promises became reality. ${ }^{21}$ In Santa Monica, Venice, or Redondo Beach, the commuting masses could go home from their downtown offices and enjoy the restorative benefits of the seaside.

Conversely, the beaches' proximity to a bustling metropolis also transformed the social and bodily practices on the sands. Although the vast majority of the metropolitan coastline was in private ownership, significant stretches of Santa Monica Bay were made up of city-owned beaches and thus, in theory, opened to everybody. ${ }^{22}$ Moreover, the coastline was easily accessible, thanks to the vast network of electric trams that crisscrossed the region. In a city famed for its lack of public space, beaches served civic, communal, and commercial functions usually shouldered by urban parks, streets, public plazas and squares. In the early twentieth century, Angelenos from all walks of life-from tramps to movie stars-came to the shores not only to sunbathe and frolic in the water, but also to socialize, flirt, exercise, parade, and, when inspiration struck, film a movie. This quotidian relationship to the seaside soon bore its fruit. Under the influence of the city, its residents, its industries, and its cultural and social institutions, a distinct Southern California beach culture emerged on the shores.

Hollywood, in particular, had a major influence over beach manners. From the moment the film industry relocated to the region in the 1900s, beach-going in Los Angeles was associated with the glamour of the silver screen. Early twentieth-century moviemakers were enthralled by the freedom of movement and dress sanctioned by the seaside location. ${ }^{23}$ Vast and often empty during the winter, Southern California beaches soon became early Hollywood's favorite shooting locations. Few people know, for instance, that the first feature-length film in the US, Enoch Arden (1911, D. W. Griffith), was filmed on the beaches of the Santa Monica Bay. ${ }^{24}$ Beaches were also ideal places to film car chases, essential scenes in "California slapstick," a brand of comedy that relied on comic physicality. ${ }^{25}$ Even more significantly for an industry based on its ability to transport audiences to faraway places, the beaches could be transformed into a variety of landscapes, from the Riviera to the Sahara Dunes. Local newspapers, such as the Palisades Del Rey Press, provide a glimpse into the intense filming activity on the shores: between 1926 and 1928, at least four film shoots took place on the sand. In 1927, the newspaper described the neighborhood excitement when Al Nathan Productions came to film an orientalist romantic drama entitled The Queen of Queens, and included a photo of the entire crew posing on the beach. ${ }^{26}$ So successful was the shoot that the studio even bought a section of coastal land. ${ }^{27}$ 


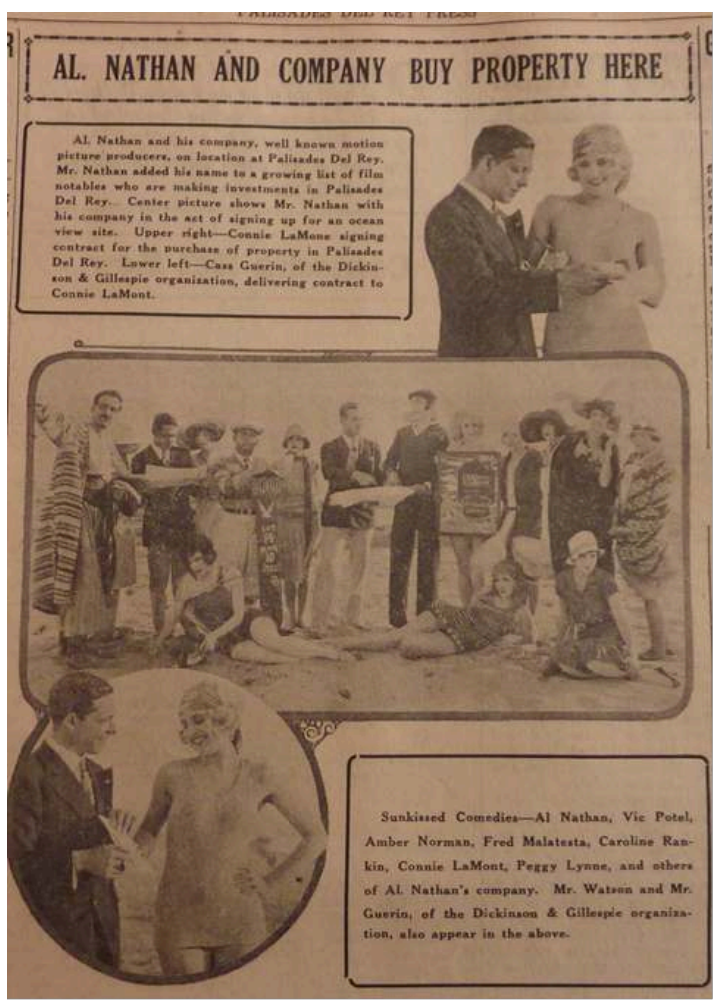

Figure 2. The Al Nathan Productions of California pose on the beach and buy beach property following a successful coastal shooting, 1927. Palisades Del Rey Press, August 15, 1927, 8. Box 8ov, Fritz Burn Papers. Department of Archives and Special Collections, William H. Hannon Library, Loyola Marymount University.

Buying property on the beach was actually quite typical among Hollywood professionals of that period. Stars, directors, and writers settled on or near the coastline, turning the city's beaches into favorite stalking grounds for autographhunters. Once a private ranch fiercely defended from trespassers, Malibu started attracting the likes of actresses Anna Q. Nilsson, Marie Prevost, and Clara Bow in the late 1920s. The beach area chosen by such illustrious residents eventually came to be known as "the Malibu movie colony." A few miles to the south, Santa Monica's "Gold Coast" was home to famous directors and actors such as Louis B. Mayer, Jesse Lasky, Douglas Fairbanks, Mary Pickford, and Marion Davies. ${ }^{28}$ By choosing to live at the beach -an usual choice at the time- stars hoped to elevate their public profiles and benefit from the booming popularity of seaside recreation. Moreover, such a move bestowed an air of eccentricity onto any film star in need of a publicity boost. In the context of Hollywood's rising star system, which pitted actors against one other, living by the beach soon became an essential marker of a true movie star. ${ }^{29}$

12 Hollywood's love affair with the beach stimulated coastal urban development, with real estate developers capitalizing on the association by giving residential developments such evocative names as "Hollywood by the Sea" and "the Hollywood Riviera." ${ }^{30}$ By the 1930s, the beaches were so central to the movie world that bus companies, such as Allison California Auto Trips, organized tours entitled "Hollywood and the Beaches," combining a visit to the inland studios with an excursion to the seaside. ${ }^{31}$ Los Angeles guidebooks suggested similar itineraries, accompanied by photographs of young women lounging on the beach wearing chic swimwear and high heels-a somewhat strange sartorial combination which nonetheless perfectly captured the promise of 
sensual glamour to be found at the intersection of Hollywood and the Pacific. Lured by exotic tales of "cabana parties by the sea," tourists came to Los Angeles to see, among other attractions, the semi-nude bodies of the stars they usually could only admire on the screen. One of the city's main selling points, in other words, was its corporeal capital as the center of the movie industry.

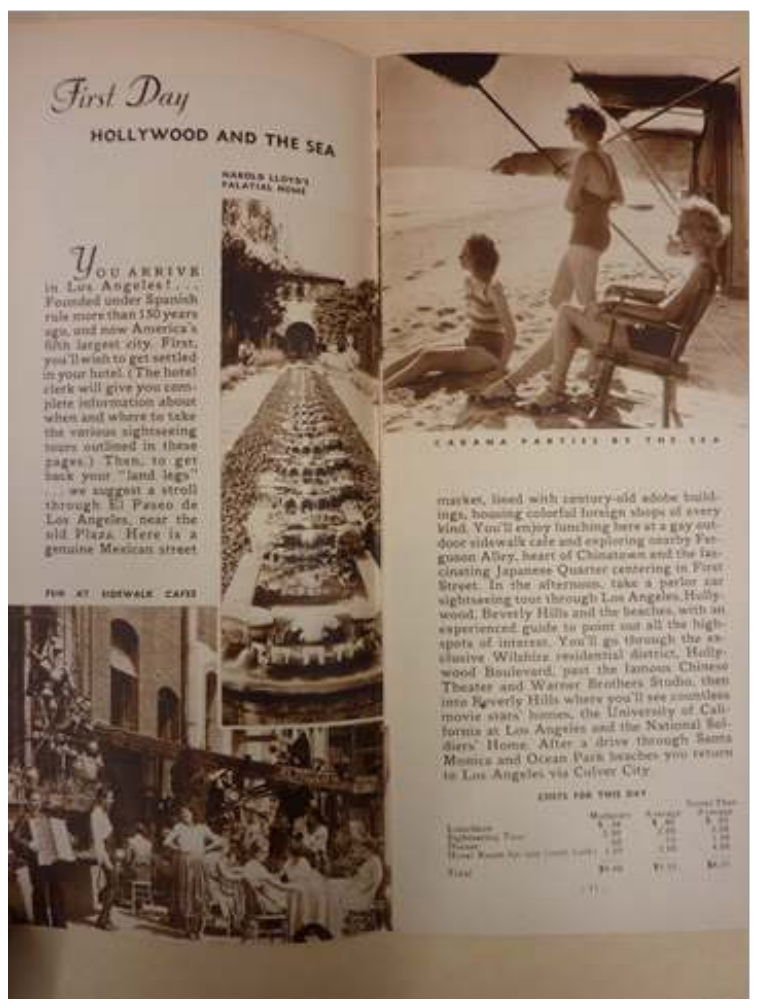

Figure 3. "A new 2 weeks vacation trip to California," guidebook itinerary by the AllYear Club, 1933. Box 10, Folder 10-10, Greater Los Angeles Visitors and Convention Bureau collection. Special Collections, Oviatt Library, California State University, Northridge.

One of the most enduring legacies of the close relationship between Hollywood and the coastline was the emergence of the bathing beauty as an icon of popular culture, which began to appear on tourist brochures promoting Southern California beach resorts in the early twentieth century. ${ }^{32}$ Although not unique to the region-beach towns throughout the US used women's bodies to lure tourists-Southern Californian bathing beauties wore more daring swimsuits and posed in a more flirtatious fashion than their counterparts on the East Coast, where conservatives had more influence over beach etiquette. Moreover, the phenomenon soon took on another dimension in Los Angeles when filmmaker Mack Sennett, inspired by local beach cultures, started using the beaches as a scenic background for his "Bathing Beauties," young, pretty, bathing-suitclad actresses, frolicking on the sand. ${ }^{33}$ These young women had little to do with any storyline, their presence essentially being an opportunity to display female beauty and semi-nudity. Even so, the ploy proved successful. ${ }^{34}$ Sennett's Bathing Beauties became so popular with the public that other studios quickly launched their own brigade of shapely actresses clad in fashionable swimwear. By the 1920s, the bathing girl had become an established screen type with its own subheading in the columns of The Standard, a casting directory. ${ }^{35}$ 

discourse on the "new woman" and the rising popularity of beauty pageants ${ }^{36}-$ it had a disproportionate impact on standards of beauty at the local level. In contrast to moviegoers in New York or Chicago, who admired the Bathing Beauties as creatures of the silver screen, as abstract icons with no connection to their daily lives, Angelenos could encounter them in both the movies and reality. Even if they didn't catch a glimpse of the young ladies while Sennett filmed his movies, they could hear about them via their local newspapers. ${ }^{37}$ The Bathing Beauties also made regular appearances at movie openings, automobile shows, and other local events. In May 1919, Ocean Park theater patrons who came to see Yankee Doodle in Berlin were also treated to the "tuneful frolics" of the "famous Mack Sennett Bathing Beauties in person." ${ }^{38}$ More significantly, Sennett systematically enrolled his Bathing Beauties in local beach beauty pageants: in 1917, members of his troupe took first, second, and third place in the Great Bathing Parade held in Venice. Sennett himself was often a judge at these events. ${ }^{39}$

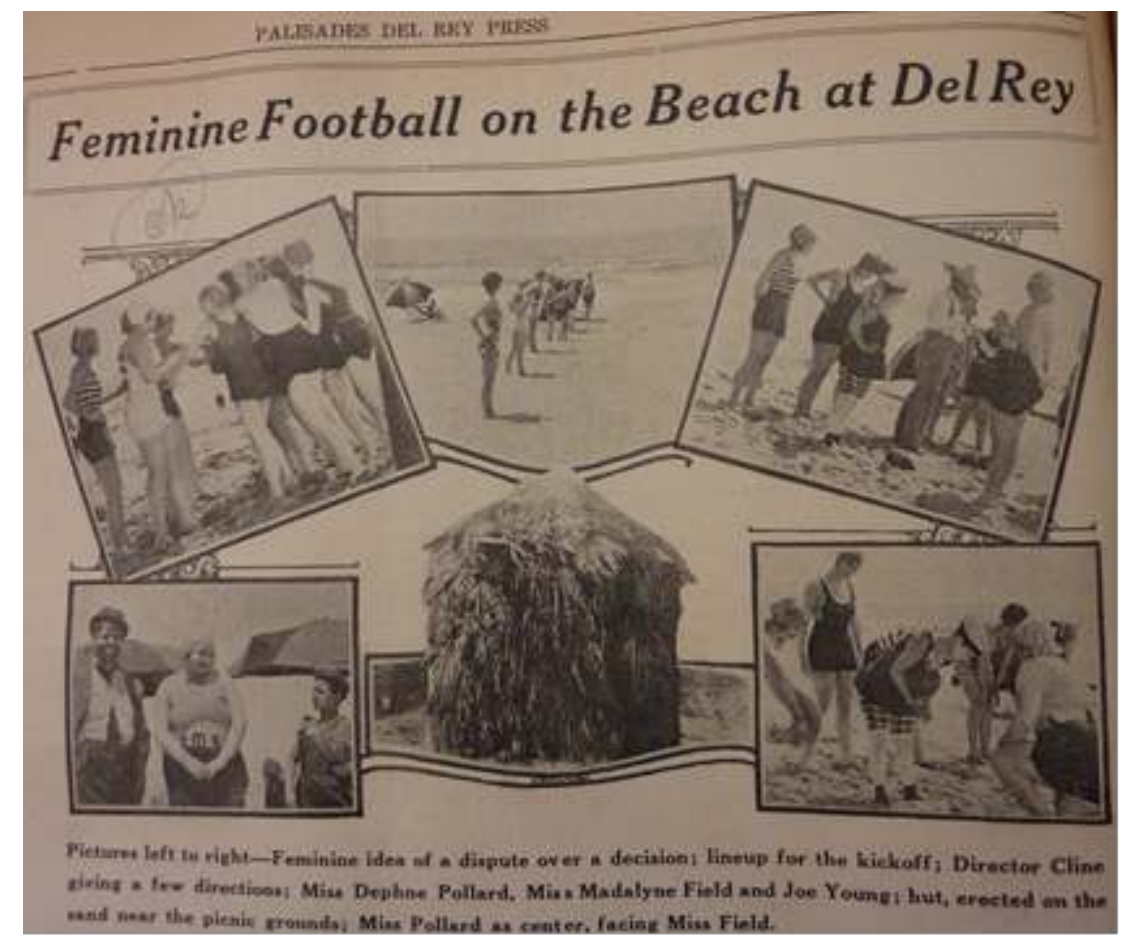

Figure 4. Mack Sennett's Bathing Beauties display their lithe and graceful bodies during a shooting on location at Palisades Del Rey. Palisades Del Rey Press, August 15, 1927, 8. Box 8ov, Fritz Burn Papers. Department of Archives and Special Collections, William H. Hannon Library, Loyola Marymount University.

The Bathing Beauties were not the only Hollywood bodily archetypes to which Angeleno beachgoers were exposed, and Sennett was not the only filmmaker to use local pageants as an opportunity for publicity: all the studios entered "their prettiest girls" in the annual Venice Bathing Parade..$^{40}$ And if not already under contract, female contestants were often lured by the prospect of winning "a screen test in Hollywood." 41 Indeed, according to the local press, many were entering "with the hope that it would prove a stepping stone into the movies." ${ }^{42}$ Hollywood even influenced the categories used in local pageants, with the 1928 Venice Bathing parade offering a prize for "most handsome male film extra." ${ }^{43}$ In other words, Hollywood beauty criteria soon became the ultimate standards against which the beach bodies of local women (and men) were 
judged. Daily exposure to such events meant that the pressure to conform was more intense in Los Angeles than anywhere else in the nation.

While the bathing girls on the silver screen were always white, local beach queens were more diverse: despite persistent forms of segregation, black Angelenos were a significant element of the nascent Southern California beach culture. Verna Williams, a young African-American woman whose family relocated from Texas to Los Angeles in the 1920s, visited the beach every Sunday. ${ }^{44}$ In photographs from her family album, now owned by the Los Angeles Public Library, Verna is clad in a bathing suit of the latest fashion, posing languorously on the sands in a manner inspired by Hollywood movies: in one of them, she is even wearing a one-piece bathing suit with the word "HOLLYWOOD" sewn down the side of her chest. ${ }^{45}$ The inscription of Hollywood on the body of this young African-American woman could not have been made more literal. Verna Williams, however, did not have access to all the beaches in Los Angeles: she mostly visited the "Inkwell," a stretch of sand in Santa Monica that was customarily known as the black beach, where African Americans were free from harassment and violence. ${ }^{46}$ African Americans with means also had the option of patronizing private beaches and beach clubs. In 1925, the Pacific Beach Club organized a pre-opening marketing event that included a well-attended "Bathing Beauty Parade," "the first ever given for our group on the Pacific Coast" according to the California Eagle, in which many "local girls" could demonstrate their "cinema aspirations." The following week, reels of the parade were shown at a movie theater in the mostly black South Central neighborhood of the city, turning the contestants, at least for the day, into stars of the silver screen. According to historian Alison Rose Jefferson, these images forced a "rearticulation of aesthetic[s]" comparable in its empowering faculty to the racial uplift rhetoric. ${ }^{47}$ The dissemination, however limited, of such events certainly instilled a sense of pride in their black spectators. It also reinscribed black bodies within regional narratives of the body beautiful.

17 In early twentieth-century Los Angeles, then, going to the beach was a glamorous affair: it meant potentially meeting a star, or even becoming one. But it also decreed that your body should always be ready for the camera. As a result, Angelenos were acutely aware of the need to prepare and shape their bodies for public display, many turning to physical exercise to achieve the beauty standards of the time. This phenomenon was national in scope: since the end of the nineteenth century and the rise of the "muscular Christianity" movement, Americans had become increasingly interested in physical activity as a means of improving the body. At the same time, changing social and cultural mores meant that excess body fat was no longer a symbol of wealth, but instead a source of mockery. While all Americans experienced these transformations, Angelenos were under additional pressure to conform: not only were athletic prowess and slenderness more revered in Hollywood than anywhere else, with the "reducing craze" reaching a peak in the 1920s, but Los Angeles' civic image was intimately linked to athleticism. ${ }^{48}$

18 As Lawrence Culver argues in The Frontier of Leisure, early twentieth-century boosters promoted outdoor recreation as an essential aspect of life in Southern California. This emphasis on athleticism was also evident in municipal policies. In 1904, Los Angeles was the first city in the country to open a municipal service entirely dedicated to recreation and playgrounds. ${ }^{49}$ Yet the municipality acquired no tracts of land in which to develop large public parks: in this new type of city, with individual bungalows 
replacing the crowded tenements of the East Coast, the logic went, there was no need for parkland. In reality, however, many Angelenos sought large, empty spaces in which to practice sports and, in the absence of a traditional park, they flocked to the city's public beaches. When the tide was low, noted the Los Angeles Times in 1904, sandy beaches "afforded a hard, smooth floor for athletic events." ${ }^{50}$ From the early twentieth century onwards, charitable and religious organizations, local schools, and businesses regularly organized beach picnics that featured racing and swimming competitions. African Americans also took part in this phenomenon: many used the private beach known as "Bruce's Beach" as a site for sporting events. ${ }^{51}$ Throughout the 1920 s and 1930s, municipalities began to provide more formal settings for children and adults to exercise, installing playgrounds and gym equipment on the sands. Wealthier residents had even more opportunities, as downtown sports clubs started opening branches on the coast. In addition to swimming, private beach clubs adapted many sports to the beach environment, including golf, polo, basketball and tennis, and provided their members with "body and beauty building classes." ${ }^{52}$ By the mid-1920s, exercising on the beach had become so popular that it was a promotional strategy employed by both Hollywood stars and real estate agencies. By circulating photographs of his employees practicing their morning calisthenics on the beach, developer Fritz Burns sought to associate his business with the active lifestyle promoted by the likes of physical culturist Bernarr Macfadden..$^{53}$ Similarly, actress Marion Davies emphasized her athleticism by staging a ball game photo shoot in front of her beach house..$^{54}$

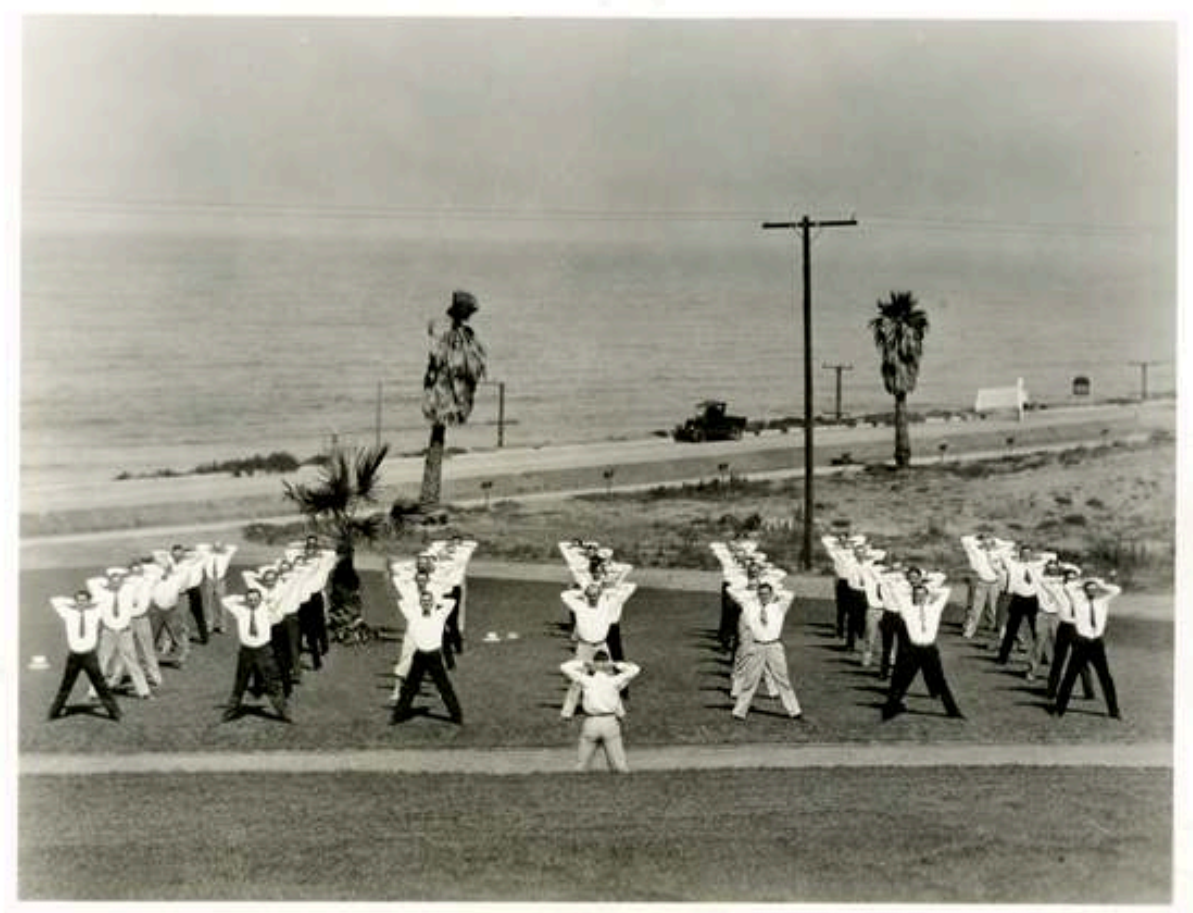

Figure 5. Every morning, employees of the Dickinson \& Gillespie real estate company practiced calisthenics on the beach. Box 5, folder 12, Fritz Burns Papers. Department of Archives and Special Collections, William H. Hannon Library, Loyola Marymount University.

Similar practices took place on the shores of Europe and the East Coast. In early twentieth-century France, for instance, the tradition of the "gymkhanas" and beach 
clubs presented opportunities for bourgeois adults and children to exercise. Yet such activities were organized with hygienic and military objectives in mind: according to historian Michel Rainis, French beach clubs were ultimately intended to prepare the next generation of soldiers. In contrast, Southern California beach sports were practiced solely with hedonistic and aesthetic goals in mind. Typical of this unique mix of fitness and fun was the Southern California tradition of the beach party, which blended features of athletic competition with more traditional forms of community celebration. The annual Catholic reunion at Ocean Park beach in 1904, for instance, featured dancing, a pie-eating competition, and a baby pageant alongside the more strenuous running, boating, and swimming races..$^{55}$ Rather than soldiers, the goal of Pacific coast recreation was to turn children into beautiful adults: this "Mecca of childhood," as the Los Angeles Times described the area, ensured the development of "perfect physical manhood and womanhood." Extolling the virtues of "aquatic sports," the paper presented "the winner of a recent thousand dollar beauty prize" and native of Santa Monica, Miss Newkirk, as an example of this physical perfection. ${ }^{56}$

The phenomenon of "Muscle Beach" is particularly representative of this mindset. Located on Santa Monica Beach near the famous recreation pier, Muscle Beach was initially opened as a municipal playground where children could exercise on gymnastic equipment, such as rings and parallel bars. By the mid-1930s, however, it had been overrun by gymnasts, athletes, and circus artists practicing their routines ${ }^{57}$ With a lively vaudeville scene in downtown Los Angeles, several wrestling and boxing arenas near the beach, a strong collegiate gymnastics presence in nearby universities, and scores of young men and women attracted to the region by the appeal of a career in the movie industry, the playground drew from a large pool of potential recruits. The addition of more equipment and a wooden platform over the following years turned the area into a permanent outdoor circus show. Unlike circus performers, however, who wore fanciful outfits and elaborate make-up, Muscle Beach habitués displayed their lithe and muscular bodies in ordinary bathing suits and wore the most elemental form of make-up: their California tans. The popular Muscle Beach spectacles also distanced themselves from more traditional gymnastic and acrobatic shows by exuding a distinct erotic appeal: beautiful men and women performing feats of strength and balance in skimpy bathing suits could not but elicit lustful appreciation from the audience. Looking was actively encouraged: every year, Santa Monica organized an annual photographic contest, inviting visitors to take "camera shots of any activity from sunbathing to acrobatics." ${ }^{58}$ Finally, there was no need for music and choreography: on the beach, the oceanic background and the athletes' cheerful laughter made for a joyful spectacle. At Muscle Beach, physical exercise and outdoor living became a performance.

21 Physical exercise as performance was not a new phenomenon on the Southern California coast. As early as the 1900s, businessmen had routinely organized swimming races and surfing and diving demonstrations to attract tourists to their beach resorts. Surfing was particularly popular with the crowds. As an ancient Hawaiian practice, surfing's exotic nature appealed to a primarily white audience. While diving and swimming races could be witnessed in nearby pools and rivers, surfing could only be performed on the breakers, thus turning the beach into a literal scene. The first and most famous surfing expert of the time was undoubtedly Hawaiian swimmer and lifesaving instructor George Freeth. Upon arriving in California in 1907, Freeth was 
hired by businessmen Henry Huntington and Abbot Kinney to demonstrate his surfing tricks at their respective resorts along the coast, Redondo Beach and Venice..$^{59} \mathrm{His}$ career inspired others to bring their surfing talents to the US: in 1912, Olympic swimmer Duke Kahanamoku also gave surfing demonstrations in the region. ${ }^{60}$

Surfing exhibitions were not unique to Southern California: Kahanamoku, for instance, also surfed in Atlantic City, in Europe, and in Australia. ${ }^{61}$ But surfing established roots nowhere as deeply as Southern California. As historian Douglas Booth has shown, the powerful influence of Christian moralists on beach manners and regulations in early twentieth-century Australia was not conducive to the rapid implementation of the sport. ${ }^{62}$ In contrast, surfing resonated with the focus on hedonism and showmanship that characterized Southern California beach cultures. Moreover, Hawaii and Southern California had enjoyed close commercial relationships since the nineteenth century. ${ }^{63}$ Following US annexation of the islands in 1898, a growing number of Californians took to vacationing on the beaches of Waikiki. By 1925, economic and cultural ties between the islands and the continent were so strong that Hawaiian booster Lorrin A. Thurston declared Hawaii "the natural companion piece to, the supplement of, Los Angeles." ${ }^{64}$ As young Hawaiians such as George Freeth and Duke Kahanamoku visited and, eventually settled in the region, they turned their passion for water sport into a means of earning a living. Water safety had become essential to Los Angeles' tourist and leisure economies ${ }^{65}$ By taking up the newly created posts of lifeguards, these young men spread the practice of surfing among their colleagues.

By the late 1920s, surfing was practiced by about a hundred, mostly male, lifeguards, swimming instructors, and professional swimmers in the region. Despite their small numbers, early practitioners of the sport were regular fixtures in the pages of the Los Angeles Times, which regaled its readers with tales of "mermen" riding the waves, and established the visual characteristics of the lifeguard/surfer as a modern icon. ${ }^{66}$ Thomas Blake, a Wisconsin native who settled in Los Angeles in 1921, played an important role in this process by documenting the emergent Hawaiian and Southern Californian surfing communities in photographs and extolling the virtues of the sport for health and fitness. Just like Kahanamoku and Freeth, Blake worked as a lifeguard for local beach clubs during the 1920s. Travelling regularly between the continent and Hawaii, he became fascinated with traditional paddle boards and surfboards, and over the following years publicized his own board designs in a book, Hawaiian Surfriders (1935), and several articles in popular magazines and newspapers. His 1935 article on Hawaiian surfing, published in National Geographic, featured a particularly striking photograph of Blake standing beside his collection of traditional Hawaiian surfboards. ${ }^{67}$ As Kristin Lawler has described, his "beach-blond, tousled hair, tan healthy skin [and his] light-colored, baggy, simple clothing," came to epitomize the "relaxed, carefree look that is associated with the beach to this day." ${ }^{68}$ In the 1930s, Olympic swimmer and actor Johnny Weissmuller further established the iconic image of the Southern California lifeguard as muscular, sun-tanned, and tall. Weissmuller, who rose to fame playing a broad-chested Tarzan in a dozen movies between 1932 and 1948, was a regular at Santa Monica beach, training with the lifeguards, and even became an honorary Los Angeles County lifeguard in $1932 .{ }^{69}$ By the early 1940s, the stereotype of the blond, muscular and suntanned lifeguard was so entrenched in the imaginaries of locals and tourists that thousands of cards were printed every summer warning beachgoers against "trying to get a tan like a lifeguard on your first visit to the beach." ${ }^{70}$ As scholars have pointed out, such a stereotype belied the Polynesian origins 
of the sport. Two non-white men, Duke Kahanamoku and George Freeth-whose mother was half Hawaiian-had introduced surfing to Southern California. Yet, by the 1930s, the representation of surfers in the media had completely erased the indigeneity of the sport.

By the end of the 1930s, Southern California had emerged as a new model of seaside leisure, characterized by its emphasis on the display of beautiful, tanned, and fit bodies. Thanks to films, photographs, and advertisements, Americans across the country imagined the Los Angeles beaches as populated by glamorous film stars and intrepid surfers. To a certain extent, the myth was based on reality: a vast array of original bodily cultures had taken root in L.A.'s Westside. Yet photographic and filmic evidence of such trends systematically erased the contributions of non-white Angelenos. Such a contradiction between representation and reality not only persisted but grew starker in the postwar period.

\section{The Postwar Triumph of the "California Look"}

For a short period between the mid-1950s and the mid-1960s, the whole of America was obsessed with Southern California beach life. The bathing beauty, surfer, and bodybuilder-the iconic figures of Southern California beach cultures-became ubiquitous in songs, films, magazines, and advertising. This obsession was part of a larger cultural movement: California exerted an enormous cultural influence over Americans during the postwar period. As Kirse Granat May explained, "the state became the postwar age personified-suburbanized, dependent on cars, and the home of the baby boomers."71 Aided by the surfing craze and seemingly endless "beach teenpics," Southern California beach cultures emerged as the perfect metaphor for the "good life." With its sweeping beaches and cinematic palm trees, the Southern California seaside was certainly, as film scholar Gary Morris has suggested, a great place in which to escape the worrying news of the time, in particular Cold War threats of nuclear annihilation and the racial tensions linked to the nascent Civil Rights Movement. ${ }^{72}$ Yet mere escapism does not fully explain this postwar fascination. What made California beaches so appealing to local and national audiences, I argue, was their role as key stages on which the new social and bodily norms of the postwar era were produced and displayed.

While corporeal prescriptions and beauty standards were not fundamentally altered in the postwar period, they were certainly intensified. Thinness, already a priority for both sexes during the 1930s, now became an absolute requirement. ${ }^{73}$ In the allimportant realm of skin pigmentation, a golden sun-kissed glow thoroughly supplanted the more traditional milk-white complexion as a woman's most prized asset. Although visible muscularity remained associated with homosexuality, men felt increased pressure to exercise and gain strength; even female homemakers were expected to exercise gently to keep their bodies toned and firm. ${ }^{74}$ Desired above all was youthfulness: in the midst of the baby boom and the rise of the teenage consumer market, films, magazines, and lifestyle journals celebrated youth in all its manifestations.

While these developments were national in scope, they found their ultimate expression in Southern California and, more specifically, on the beaches of Los Angeles. The prewar trend for the city's shores to be breeding grounds for subcultures centered on the 
display and active cultivation of beauty, fitness, and youth continued and intensified. In addition to surfing - a full-blown craze by the early 1960s-droves of Angelenos took up beach volley-ball, water-skiing, diving, boating, and beach acrobatics. Up to 5000 people attended the Muscle Beach weekend shows; 30,000 Californians rode the waves; and every year at Easter, over 80,000 high school and college students flocked to the beach to sunbathe and parade around Balboa Island celebrating "Bal Week" (a local version of Spring Break). ${ }^{75}$ "Muscle-Beachers," spring-breakers, surfers, and other "beach bums" not only found relaxation and a sense of belonging on the shores, they sought to shape and display their bodies in a combination of traditional seaside hedonism with an ethos of bodily discipline.

Muscle Beach athletes best embodied this unique combination. In the postwar period, the arrival of a growing contingent of bodybuilders among the playground regulars turned the local attraction into a national phenomenon. As an underground subculture mainly practiced indoors by prison inmates, gawky adolescents, and working-class men, bodybuilding represented a novel spectacle. ${ }^{76}$ Journalists from across the country flocked to the beach to report on the musclemen's strange habits and lingo. In the eyes of East Coast reporters, Muscle Beach was one weird place. ${ }^{77}$ Most beach-lovers, explained journalist Joel Sayre, went to the ocean to enjoy a variety of pleasures: "casual swimming and wave riding, acquiring a tan, snoozing off a hang-over, gossip, picnicking, letting the kids blow off steam, playing a little volleyball, sizing up the pretty girls, and so on." But the pleasures of Muscle Beach athletes "[were] not precisely those that most people go to beaches for." According to Sayre, the regulars were "too serious and too busy for such frivolous pastimes," and Muscle Beach itself "serve[d] far less as a beach per se than as a unique three-acre, open-air gymnasium." ${ }^{8}$ All commentators agreed that such dedication to the body was both admirable and excessive. Since the nineteenth-century beach-bathing boom, the seaside experience had traditionally been associated with liberation from social restraints and work disciplines. Historian John Kasson described early twentieth-century Coney Island as "an invitation to collective gaiety and release," standing "against the values of thrift, sobriety, industry and ambition." 79 While "Muscle Beachers" were certainly full of gaiety, they were also hard-working and ambitious. Many regulars had started learning acrobatics from as young as three, and exercised every single day. Some, like veteran coach Barney Frey, "concocted special vitamin pills" and stuck to a rigorous diet. ${ }^{80}$ Others had careers in professional sports and strove to reach their maximum potential, while those dreaming of a Hollywood career sculpted their bodies accordingly. ${ }^{81}$ At Muscle Beach, discipline was key, as in the case of Dave "Hymie" Schwartz, once a "physical wreck weighing but $85 \mathrm{lbs}$. as a result of yellow jaundice and malaria" who, after three years of arduous training at the beach, became an accomplished weightlifter. ${ }^{82}$ The beach was a place for fun, but it also functioned as a site where one could parlay one's body into a career in the movies or in sports.

Southern California surfers also drew attention from East Coast journalists for their monomaniacal dedication to the sport. In countless magazine and newspaper articles relating the rapid transformation of the once obscure subculture into a "favorite summertime sport," surfers were praised for their discipline and, at the same time, regarded with concern for their seemingly addictive relationship with the ocean. ${ }^{83}$ Learning how to surf was "no small job," and mastering its intricacies required daily practice: "After school, after work over a weekend, or just at any time at all [surfers] trek down to the beach." ${ }^{\prime 4}$ In contrast to the image that existed in popular culture of 
surfers as lazy slackers, many accounts celebrated their devotion to their bodies: "Keeping fit," explained a San Francisco native who swam a mile several times a week and ran a mile every other day, "was vital to survive in this sport." ${ }^{85}$ Journalists could not but acknowledge surfing's positive impact on the body. With his bronze suntan and boyish smile, John Severson, the successful founder of Surfer magazine, was the finest example of "the beneficent result of the good California beach life that he espouses." 86 Most importantly, surfing was "an excellent form of exertion to keep the figure trim." "You never see a fat surfer," commented a young swimming instructor in The Los Angeles Times. ${ }^{87}$ Thus surfing was particularly recommended to young women, and described as one of the secrets behind the luscious physiques of California girls. ${ }^{88}$

The surfers and athletes' hard work paid off: journalists agreed that Los Angeles' beaches offered some exceptional specimens of human pulchritude. The annual Miss and Mister Muscle Beach contests, first held in 1947, became the high point of the year and an opportunity to display the group's most exceptional physiques. The contests differed from regular beauty pageants by emphasizing muscularity and a general athletic appearance. "Beauty alone is not enough," explained a TV reporter sent to cover the 1954 Miss Muscle Beach contest: the winner also had "to possess effective working sinews too and know how to flex them." ${ }^{89}$ Yet the shapely young women who walked off with the Miss Muscle Beach trophy still corresponded to dominant standards of beauty. Many were Hollywood models who collected beauty-queen titles on the side, and all boasted ideal bust, waist, and hip measurements. ${ }^{90}$ As for the lucky winner of the Mister Muscle Beach title, he had to be "of Mr America caliber" claimed physical culture magazine Strength \& Health. While mainstream journalists often ridiculed bodybuilders, by the mid-1950s they were forced to acknowledge that "muscles were here to stay." ${ }^{11}$ If some women certainly saw the erotic appeal of musclemen, many men also did. Muscle Beach was located just a few yards from Crystal Beach, L.A.'s unofficial gay beach, and it was well known that the muscle shows attracted gay men for their homoerotic undertones. The sexiness on stage eventually became too much for Santa Monica's civic elites: in 1958, the playground was closed on the pretext that five Muscle Beach habitués had been accused of sexual misconduct. ${ }^{92}$ The erotic display of semi-nude bodies was authorized, but only as far as it remained constrained within the parameters of "sexual liberalism" and the heterosexual gaze. ${ }^{93}$

31 Not all beach-goers were as dedicated to the body beautiful as Santa Monica bodybuilders and Malibu surfers, but everyone was encouraged to get active when at the beach. With official sponsorship from the city of Santa Monica's Department of Recreation, Muscle Beach offered free classes in "adult weight lifting" and "children's acrobatic." ${ }^{94}$ Similarly, Venice Beach's weight-lifting area, opened in 1950, was the ideal place "to tighten flabby muscles and trim off pounds." ${ }^{95}$ Beach-goers simply had to be active: as the Los Angeles Times warned in 1960, “you can't go to the beach these days with just a swim suit." Southlanders were expected "to trail a boat, pack diving gear, tote water skis and... load the surfboard." ${ }^{\prime 6}$ Moreover, all Angelenos knew that there were strict yet unspoken rules when it came to one's physical appearance at the beach. In California: The New Society, the Californian journalist Remi Nadeau, who wrote several books on the strange customs of his native region, attempted to lay down these rules for the uninitiated: "At the beach you must not wear regular clothes, such as pants, skirts or shoes," he noted. Doing otherwise was akin to "wearing shoes in a mosque; it is a sacrilege against the sun-god." Accordingly, beach umbrellas were to be shunned, and a good suntan was de rigueur. Overall, Nadeau insisted, "you must exhibit some 
evidence of the outdoor life." Interestingly, Nadeau concluded by explaining that these rules actually applied "not only at the beach but in your own community." "Even if you are not a beachgoer, he warned, the possibility of being invited over to a neighbor's pool is a powerful incentive to get a tan." ${ }^{97}$ In sunny Los Angeles, where opportunities to disrobe were legion, sporting the external marks of a beach-going life, even if you did not actually frequent the seaside, was a "hip" sign of youthfulness.

of course, beach-goers engaged in similar bodily practices in other coastal cities, such as Rio de Janeiro and Sydney. In Los Angeles, however, these new practices fed into and reflected the body cultures promoted by Hollywood and the entertainment industry. Just as early Hollywood's obsession with the shores had transformed the bathing beauty from a quaint female image usually found on local tourist brochures to a popular cultural archetype, Muscle Beach turned into a national phenomenon thanks to the resident movie industry. Not only did Hollywood provide work for many athletes as stuntmen and extras for gladiator films, but Muscle Beach itself attracted and inspired local filmmakers, television producers, and writers. One of the first filmmakers to point his camera at the athletes was Joseph Strick in 1948. His short documentary film, entitled "Muscle Beach," received high praise from critics around the world, who were charmed by this "impressionist report of a sunny day on an American beach." ${ }^{98}$ In the subsequent years, the site was used as an eccentric background by local television programs, films and novels, often mocking the lifestyle of Hollywood hopefuls. ${ }^{99}$ Similarly, the growing popularity of surfing was inextricably linked to its success on the big and small screens. The movie Gidget (1959), adapted from a popular novel set in Malibu and describing the adventures of a suburban teenage girl turned surfer, is often credited for having launched the surfing craze. ${ }^{100}$ The film's box office success not only inspired two sequels and a television series, but also led other studios to take note of surfing's popularity: in the following decade, Hollywood produced over sixty surfing-inspired films targeting the coveted teenage market. Most famous among these were the series of Beach Party movies produced by American International Pictures (AIP), including the Muscle Beach-inspired Muscle Beach Party (1964). By 1964, Hollywood had produced so many "beach movies" that Leo Carillo beach, a popular strand of the Los Angeles area, "ha[d] become one of the busiest 'sets' in California," thus continuing a long tradition of filming on the sands. ${ }^{101}$ While the setting was an integral aspect of the films' success, their appeal also lay in the beautiful bodies they displayed. AIP producer James Nicholson readily admitted that "beach bunnies in bikinis" and "barechested surfers" were a prime attraction for the teenaged boy and his girlfriend heading to the theater. But such luscious bodies could not be manufactured in studios. ${ }^{102}$ According to AIP director William Asher, who had recruited most of his films' extras on Malibu beaches, "the only way you c[ould] look the way these kids look [wa]s to live on the beach." ${ }^{103}$ Hollywood's love affair with the beach not only gave a regular source of income to local "beach bums," but turned surfing into a lucrative activity for some of its most photogenic practitioners. In 1966, surfing champion Mary Lou McGinnis readily admitted that the sport could lead "to a more solid career as a model and actress." ${ }^{104}$ In other words, Los Angeles' beaches in the postwar period morphed into outdoor factories, sculpting modern bodies for the immediate consumption of onlookers and, eventually, television and film audiences. Conversely, surfing-inspired advertising and films led teenagers across the US and elsewhere to emulate the look of their bronze-skinned heroes. If landlocked teens could not experience the California lifestyle at the heart of "surfsploitation films," they could 
at least try to achieve a similar look by using beauty products, diets, and exercise methods. The surfing craze and its Hollywood and Madison Avenue byproducts thus made the "California look" truly national.

By the 1960s, as Shelly McKenzie has stated, "the California lifestyle was transformed into a physical aesthetic: thin, tan, taut bodies with sun-bleached blond hair and pearly white teeth." 105 The "California look," as it came to be called, was the hybrid product of Angelenos' daily engagement with varied corporeal practices and the entertainment industry's embrace of such practices. While it did reflect the liveliness of local beach cultures, it failed to acknowledge the active participation of non-white Angelenos in this scene. Muscle Beach, for instance, was one of the most integrated stretches of Santa Monica Beach. ${ }^{106}$ Photographs of the Mister Muscle Beach contests show black, Asian, and Latino participants, and in 1950 the coveted title was won by 23-year-old Joe "Pepper" Gomez, a young regular of Latino descent. ${ }^{107}$ The female athlete population was less diverse. Blonde or brunette, every single Miss Muscle Beach over the years was white. African-American women did take part in local beach beauty contests, as was already the case before the war, but their photographs appeared only in black newspapers: every year, contestants in the Miss Bronze Los Angeles and Miss Bronze California posed in fashionable bathing suits with a dreamy beach background for the LA Sentinel. Women who won these all-black contests complied with all but one of the beauty standards their white counterparts had to follow, and were similarly expected to visit "the beach regularly to keep in shape" and display "graceful and lithe bodies." "108 Black Angelenos even took the L.A. beach culture inland, organizing the Miss Val Verde and Mr. Muscle Man beauty contests in the peaceful confines of the Val Verde resort, an African-American heaven located about forty miles from the coast. The winners of these contests, which took place from the 1940s until the 1970s, also graced the pages of local black newspapers. ${ }^{109}$ Just as these photographs were confined to African-American newspapers and magazines, surf music and movies-whether "authentic" or in their watered-down Hollywood versions-still systematically depicted practitioners of the sport as white. In 1965, Ebony, a major national magazine targeting a black readership, provided a rare glimpse of the black surfing scene in Los Angeles by dedicating a photo essay to Frank Edwards, an 18-year-old African-American surfer from Hermosa Beach who had placed fourth in a recent international surfing competition. ${ }^{110}$ Edwards was described as "one of a minute number of Negroes who have taken up the sport of surfing." The foundation of a black surfing association only a decade later, however, indicates this observation was not entirely accurate ${ }^{111}$ Minority Angelenos were not only systematically sidelined by the mainstream media; even black papers underestimated their participation in Southern California beach cultures. This erasure explains why the "California look" emerged as such a coherent and selfcontained form of imagery in postwar popular culture.

As many scholars of the body have shown, there is nothing natural or obvious about our contemporary obsession with thinness, musculature, and tanned skin. Nor is our ability to identify a certain "West coast-ness" in the corporeal realm. Yet there is indubitably a set of body markers and attitudes that anyone exposed to Hollywood films and advertising can recognize as specifically Southern Californian. From the blond and tanned surfers of Malibu to the well-oiled bodybuilders of Venice, the region's infamous "beach bums" share the sought-after markers of an active lifestyle and a distinct combination of strict body discipline and sultry hedonism. This particular set of "body techniques" and its associated mentality hark back to the 
beginning of the twentieth century when Los Angeles expanded towards the Pacific, giving birth to the Westside, an entire area of the city dedicated to seaside pleasures and the quest for "body perfection." 112 The long-standing promotion of the Southern California climate as a health miracle, Hollywood's partiality to the eccentricities of beach living, and the centrality of athleticism and Hawaiian cultures to regional identity explain why "Westsiders" engaged with their coastlines and bodies with such intensity and devotion. From the 1920s onwards, consumer capitalism, aided by the rise of the beauty, exercise, and diet industries, transformed these local pursuits of health and fitness into a marketable lifestyle that emphasized physical display. ${ }^{113}$

In the postwar era, the Los Angeles coastline became a central theater of performance for subcultures that reshaped notions of beauty, masculinity, and femininity. Other coastal regions also harbored self-styled "beach bums" and beauty queens. But in Southern California men and women prepared their beach bodies while on the beach, transforming what was perceived elsewhere as a place of relaxation into a site of exertion. Unlike on the East Coast, where beer bellies and blotchy skin were compatible with the beach experience as long as relaxation and fun was available, the Southern California shoreline required bodily, as well as skin-centered, discipline. Moreover, in Los Angeles, the intense activity on the shores inspired countless magazine and newspaper articles, films, television shows, novels, and plays. Filmic and photographic images, because they "necessarily entail the use of the codes and conventions of the available cultural forms of presentation," played a particularly influential role in translating multifaceted and multiracial body cultures into recognizable cultural symbols. ${ }^{114}$ Once projected on the screen or the glossy pages of magazines, Los Angeles' vibrant beach cultures were reduced to a coherent set of body aesthetics: sun-bleached hair, tanned skin, and a fit body. In that short decade from the mid-1950s until the mid-1960s, when Americans across the nation projected their desires and longings onto the sandy shores of Southern California, L.A. became short for "California," and the outdoor lifestyle was reified into a "look," the California look.

"Under late capitalism," Sarah Shrank writes, "the body is the perfect commodity": inevitably flawed and yet incessantly touted as perfectible. ${ }^{115}$ The California look proved a particularly successful body ideal to peddle in the consumer marketplace. It sold everything from Cole swimwear to Camel cigarettes, all the while shoring up the tanning, diet, and exercise industries. While it remained hard to attain for most white Americans lacking the correct physical attributes (long legs, blond hair, etc.) or the time and money necessary to secure them, for non-white Americans, including those residents of Southern California who engaged with its outdoor lifestyle, it was quite simply out of reach. Just like other West Coast commodities-from Sunkist oranges to Mission-style adobe buildings-Southern California beach bodies were whitewashed upon reaching a national audience. ${ }^{116}$ This myth held fast: in 1989, a Vogue journalist could still write without any hint of irony that what immediately "comes to mind" when thinking of California is "tanned skin, bleached hair, and lean bodies." ${ }^{117}$ The enduring cultural influence of the California look, in spite of Southern California's increasingly diverse demographics, is both a tribute to the work and passion of local boosters and beachgoers and a symbol of modern capitalism and its ability to reduce multiracial cultures to white spectacles. 


\section{NOTES}

1. Life, January 1, 1951, p. 45-50; Life, January 22, 1951, p. 8.

2. Shelly McKenzie, Getting Physical: The Rise of Fitness Culture in America (Lawrence: University Press of Kansas, 2013), 100.

3. Carey McWilliams, Southern California: An Island on the Land (Santa Barbara, CA: Peregrine Smith, 1973), 110.

4. Farnsworth Crowder, "Where Life Is Better-For What?" Westways, 28 (November 1936), 21-24.

5. McWilliams, Southern California, 110.

6. Kevin Starr, The Dream Endures: California Enters the $1940 \mathrm{~s}$ (New York: Oxford University Press, 1997), 4.

7. Jonathan Black, for instance, makes the distinction between the indoor gym culture of the East Coast, exemplified by the sweaty musclemen of the "York Gang" (a group of weightlifters based in York, Pennsylvania, who competed under the patronage of Bob Hoffman, the president and founder of the York Barbell company, and a weightlifting enthusiast), and the frenzy for outdoor exercise on the West Coast but his analysis is restricted to postwar Muscle Beach and the famous names associated with it. Shelly McKenzie identifies the popularity of "California living" as a factor behind the increase in interest towards exercise in the postwar period, but her study is national in scope, and thus relies on sources such as films and magazines.

8. Kirse Granat May, Golden State, Golden Youth: The California Image in Popular Culture, 1955-1966 (Chapel Hill: University of North Carolina Press, 2002); Claudia Bohn-Spector, "Lust in the Land of Sunshine. The Body in Los Angeles Photographs," in This Side of Paradise: Body and Landscape in Los Angeles Photographs (London and New York: Merrell, 2008), 70.

9. The phrase "California Look" has also been used to designate the style of housing and domestic interior furnishing specific to the Golden State. However, in both cases, whether for bodies or design, the phrase applies to practices and objects that actually emerged in the southern half of the state. A more accurate phrase would be "Southern California look" but, over the years, the more succinct version prevailed in common parlance. See Wendy Kaplan, California Design, 1930-1965 Living in a Modern Way (Boston: MIT Press, 2011), 27-28.

10. On the concept of cultural fetishism and the body, see Jon Stratton, The Desirable Body: Cultural Fetishism and the Erotics of Consumption (Champaign: University of Illinois Press, 2001).

11. William F. Deverell, “The Los Angeles 'Free Harbor Fight,"” California History 70, no. 1 (March 1991): 12-29.

12. Catherine Cocks, Tropical Whites: The Rise of the Tourist South in the Americas (Philadelphia: University of Pennsylvania Press, 2013), 100.

13. Kevin Starr, Inventing the Dream: California through the Progressive Era (New York: Oxford University Press, 1985), 100. 
14. Quoted in McWilliams, Southern California, 99. See also John E Baur, The Health Seekers of Southern California, 1870-1900, Huntington Library Publications (San Marino: Huntington Library, 1959).

15. On the "invention of the beach", see Alain Corbin, The Lure of the Sea: The Discovery of the Seaside in the Western World, 1750-1840 (Berkeley: University of California Press, 1994).

16. Patricia Lee Daigle, "American Tan: Modernism, Eugenics, and the Transformation of Whiteness" (unpublished PhD dissertation, University of California-Santa Barbara, 2015).

17. Ronald A. Davidson, "Before 'Surfurbia': The Development of the South Bay Beach Cities through the 1930s," APCG Yearbook 66 (2004): 81-94; Fred W. Viehe, "Black Gold Suburbs: The Influence of the Extractive Industry on the Suburbanization of Los Angeles, 1890-1930," Journal of Urban History 8, no. 1 (November 1981): 3-26; Eric Avila, Popular Culture in the Age of White Flight: Fear and Fantasy in Suburban Los Angeles (Berkeley: University of California Press, 2004), 107-13.

18. Jeremiah B. C. Axelrod, Inventing Autopia: Dreams and Visions of the Modern Metropolis in Jazz Age Los Angeles (Berkeley: University of California Press, 2009); Greg Hise, Magnetic Los Angeles: Planning the Twentieth-Century Metropolis (Baltimore: Johns Hopkins University Press, 1999).

19. Palisades Del Rey Press, May 15, 1926, 8; Palisades Del Rey Press, February 1, 1926, 6. Fritz Burns Papers, Box 8ov, Loyola Marymount University (later FBP-LMU).

20. Reyner Banham, Los Angeles: The Architecture of Four Ecologies (New York and London: Penguin Books, 1971), 38.

21. See chapter 2 in Lawrence Culver, The Frontier of Leisure: Southern California and the Shaping of Modern America (New York: Oxford University Press, 2010).

22. In 1938, the public owned only $27 \%$ of the beach frontage in the county, but large sections of the popular Santa Monica, Redondo, and Venice beaches were public. Los Angeles County, The Master Plan of Shoreline Development for the Los Angeles County Regional Planning District (1940), 4.

23. Nancy Mowll Mathews, Moving Pictures: American Art and Film 1880-1910 (Manchester, VT: Hudson Hills Press, 2005), 92-93.

24. Starr, Inventing the Dream, 292. The film is available on YouTube at https:// www.youtube.com/watch?v=ZNvb9X9QafA.

25. Gabriel Solomons, World Film Locations. Los Angeles (Chicago: University of Chicago Press, 2011), 27.

26. Palisades Del Rey Press, August 15, 1927, 8. FBP-LMU.

27. Palisades Del Rey Press, August 1, 1927, 3. FBP-LMU.

28. David K. Randall, The King and Queen of Malibu: The True Story of the Battle for Paradise (New York: W. W. Norton \& Company, 2016); Paula A. Scott, Santa Monica: A History on the Edge (Mount Pleasant, SC: Arcadia Publishing, 2004), 95.

29. Richard DeCordova, Picture Personalities: The Emergence of the Star System in America (Champaign: University of Illinois Press, 2001).

30. John Steven McGroarty, Hollywood Riviera (Los Angeles: Clifford R. Reid Company, 1921); Santa Monica Evening Outlook, June 14, 1929, 18. 
31. Folder "tours," box 28, Ephemera Collection 1299, Seaver Center for Western History, Natural History Museum of Los Angeles County, Los Angeles.

32. See for instance "Redondo Beach," Los Angeles and Redondo Railway brochure, 1900 and "Redondo Beach and the Pleasures You May Have There," 1920, both held by the Huntington Library, San Marino, California.

33. According to Rob King, Sennett was inspired by a story published in a local newspaper. King, The Fun Factory: The Keystone Film Company and the Emergence of Mass Culture (Berkeley: University of California Press, 2009), 210.

34. Hilde D'Haeyere, “Splashes of Fun and Beauty. Mack Sennett's Bathing Beauties," in Rob King and Tom Paulus, eds., Slapstick Comedy (London: Routledge, 2010), 210.

35. See for instance, the Mermaid Comedies' bathing girls, featured in the 1924 movie parade, Los Angeles Times, August 2, 1924, A1; Heather Addison, Hollywood and the Rise of Physical Culture (London: Routledge, 2003), 108-9.

36. Angela J. Latham, "Packaging Women: The Concurrent Rise of Beauty Pageants, Public Bathing and Other Performances of Female Nudity," Journal of Popular Culture 29, no. 3 (Winter 1995): 149-67; Lois Banner, American Beauty: A Social History through Two Centuries of the American Idea, Ideal, and Image of the Beautiful Woman (New York: Alfred A. Knopf, 1983), 249-61; Kathy Peiss, Cheap Amusements: Working Women and Leisure in Turnof-the-Century New York (Philadelphia: Temple University Press, 1987); Martha H. Patterson, Beyond the Gibson Girl: Reimagining the American New Woman, 1895-1915 (Champaign: University of Illinois Press, 2005).

37. See for instance "Feminine Football on the Beach at Del Rey", Palisades Del Rey, August 15, 1927, 8.

38. Santa Monica Evening Outlook, May 24, 1919, 4.

39. King, The Fun Factory, 244; D'Haeyere, "Splashes of Fun and Beauty," 213.

40. Los Angeles Times, May 4, 1916, III2.

41. Santa Monica Evening Outlook, June 22, 1936, 1.

42. Santa Monica Evening Outlook, May 31, 1928, 6.

43. Santa Monica Evening Outlook, May 23 1928, 2.

44. The transcript of her 1991 interview is available online: http://173.196.26.181/ catalog/shades/transcripts/Verna_Williams.pdf

45. The photograph is available online; the user fee was too high to include it in this article: https://tessa.lapl.org/cdm/singleitem/collection/photos/id/80502/rec/4

46. Douglas Flamming, Bound for Freedom: Black Los Angeles in Jim Crow America (Berkeley: University of California Press, 2006), 272-75; Alison Rose Jefferson, “African-American Leisure Space in Santa Monica," Southern California Quarterly 91, no. 2 (2009): 155-89.

47. California Eagle, August 28, 1925, 1; California Eagle, September 11, 1925, 7; California Eagle, September 18, 1925, 1. Alison Rose Jefferson, "Leisure's Race, Power and Place: The Recreation and Remembrance of African Americans in the California Dream," (unpublished PhD dissertation, University of California-Santa Barbara, 2015), 454. Photographs of the event are printed in Deborah Willis, Posing Beauty: African American Images from the 1890s to the Present ((New York: W.W. Norton \& Co., 2009), 122-123.

48. See chapter 1 in Addison, Hollywood.

49. Culver, The Frontier of Leisure, 63. 
50. Los Angeles Times, August 25, 1904, 7.

51. See, for instance, California Eagle, July 23, 1921, 2.

52. Los Angeles Times, July 2, 1926, B4 ; Los Angeles Times, July 16, 1926, B4 ; Santa Monica Evening Outlook, June 2, 1929, 14.

53. See photographs in boxes 4 \& ov. 5 , Folder 12, FBP-LMU.

54. "Marion Davies and Her Colonial Beach Home, Santa Monica," Werner Von Boltenstern Postcard Collection, Loyola Marymount University. Available online at http://digitalcollections.lmu.edu/cdm/landingpage/collection/chgface.

55. Los Angeles Times, August 25, 1904, 7.

56. Los Angeles Times, July 31, 1904, C11.

57. Harold Zinkin and Bonnie Hearn, Remembering Muscle Beach: Where Hard Bodies Began: Photographs and Memories (Santa Monica: Angel City Press, 1999); Marla Matzer Rose, Muscle Beach (New York: St. Martin's Griffin, 2001); Elsa Devienne, “The Life, Death, and Rebirth of Muscle Beach: Reassessing the Muscular Physique in Postwar America, 1940s-1980s," Southern California Quarterly 100, no. 3 (August 2018): 324-67.

58. Santa Monica Evening Outlook, July 16, 1940, 5.

59. Arthur C. Verge, "George Freeth: King of the Surfers and California's Forgotten Hero," California History 80, no. 2/3 (2001): 82-105.

60. Tom Blake, Hawaiian Surfriders (Redondo Beach: Mountain and Sea, 1998), 61.

61. Matt Warshaw, The History of Surfing (San Francisco: Chronicle Books, 2010), 55.

62. Douglas Booth, Australian Beach Cultures: The History of Sun, Sand and Surf (London: Routledge, 2012), chapter 2.

63. Gary Y. Okihiro, Island World: A History of Hawai'i and the United States (Berkeley: University of California Press, 2008), 149.

64. Lorrin A. Thurston, "What Hawaii Really Means to Southern California," Los Angeles Times, January 1, 1925, E2.

65. Arthur C. Verge, Santa Monica Lifeguards (Chicago: Arcadia Publishing, 2007) and Los Angeles County Lifeguards, (Arcadia: Chicago, 2005).

66. See, for instance, Los Angeles Times, April 13, 1924, H1.

67. Tom Blake, “Waves and Thrills at Waikiki," National Geographic 67 (May 1935): 597604.

68. Kristin Lawler, The American Surfer: Radical Culture and Capitalism (London and New York: Routledge, 2011), 74.

69. Verge, Los Angeles County Lifeguards, 52.

70. “Surf Bathers Will Get 15 Don'ts for Safety," Los Angeles Times, April 14, 1941, A3.

71. May, Golden State, Golden Youth, 4-5.

72. Gary Morris, "Beyond the Beach. Social \& Formal Aspects of AIP's Beach Party Movies," Journal of Popular Film and Television 21, no. 1 (1993): 2-12.

73. Roberta Pollack Seid, Never Too Thin: Why Women Are at War with Their Bodies (New York: Prentice Hall Press, 1989); Schwartz, Never Satisfie d; Elizabeth M. Matelski, Reducing Bodies: Mass Culture and the Female Figure in Postwar America (New York: Routledge, 2017).

74. McKenzie, Getting Physical, 70-71. 
75. These figures are mentioned respectively in Santa Monica Evening Outlook, July 5, 1950, 13; Life, September 1961, 48; Newport Harbor Daily Pilot, April 3, 1961, 1.

76. Lynne Luciano, "Muscularity and Masculinity in the United States: A Historical Overview," in The Muscular Ideal: Psychological, Social, and Medical Perspective s (Washington, D.C.: American Psychological Association, 2007), 41-65; Dominique Padurano, "Making American Men: Charles Atlas and the Business of Bodies, 1892-1945" (unpublished PhD dissertation, Rutgers University, 2007).

77. 3000 people attended the July 4 th show in 1950. Strength and Health, November 1950 , 9.

78. Joel Sayre, "The Body Worshipers of Muscle Beach," Saturday Evening Post, May 5, 1957, 35 \& 136.

79. John F. Kasson, Amusing the Million: Coney Island at the Turn of the Century (New York: Hill \& Wang, 1978), 49-50.

80. Sayre, "The Body Worshipers," 138.

81. Los Angeles Times, February 9, 1953, 2.

82. Strength and Health, November 1950, 9.

83. Life, May 24, 1963, 70; Saturday Evening Post, June 14, 1958, 38; Life, August 7, 1939; the figure of 100,000 practitioners is mentioned in Wall Street Journal, July 22, 1963, 1.

84. Los Angeles Times, August 4, 1957, E8; Life, August 26, 1940, 50-52.

85. Life, May 24, 1963, 70.

86. Life, September 9, 1966, 37; see also the description of surfboard makers Tom Flaherty and Dale Velzy in Los Angeles Times, May 29, 1960, J1.

87. Los Angeles Times, June 23, 1963, GB1; Los Angeles Times, August 26, 1962, WS1.

88. Life, October 19, 1962, 119.

89. [Hearst newsreel footage. Santa Monica, muscle queen, tape 1, CS1701], July 1954, UCLA Film \& Television Archive, Los Angeles.

90. Los Angeles Times, August 5, 1957, 2; Los Angeles Times, August 4, 1958, 2.

91. Los Angeles Times, May 17, 1948, A11; Los Angeles Times, April 17, 1956, A5.

92. Devienne, “The Life, Death, and Rebirth of Muscle Beach,” 352-353.

93. John D'Emilio and Estelle B. Freedman, Intimate Matters: A History of Sexuality in America (Chicago: University of Chicago Press, 1997), 241.

94. 1953-1954 program, Department of Recreation, City of Santa Monica. Folder 3, Box 97, California Ephemera Collection, Charles E. Young Research Library (YRL), UCLA.

95. Santa Monica Evening Outlook, July 2, 1951, 9.

96. Los Angeles Times, May 29, 1960, J1.

97. Remi A. Nadeau, California: The New Society (Philadelphia: D. McKay Co., 1963), 50-57.

98. Today's Cinema, November 20, 1950, folder 8, box 2, Irving Lerner papers, YRL, UCLA.

99. See the script for an original teleplay by Carl Leo Gass set at Muscle Beach. Box 18, folder 4, Jerry Fairbanks Productions Records, YRL, UCLA; see also ads for a special episode of NBC-TV "Today" show dedicated to "The Body Worshipers of Muscle Beach," Los Angeles Times, May 21, 1957, 19; Ira Wallach, Muscle Beach (Boston: Little, Brown, 1959).

100. May, Golden State, Golden Youth, 75. 
101. New York Times, December 13, 1964, X9.

102. Cited in Joan Ormrod, "1960s Surfsploitation Films: Sex, the Bikini and the Active Female Body," Film, Fashion \& Consumption 7, no. 2 (2018): 153; see also Ormrod, "Issues of Gender in Muscle Beach Party (1964)," Scope, December 2012, online journal.

103. Life, July 16, $1965,87$.

104. Los Angeles Times, September 11, 1966, W58.

105. McKenzie, Getting Physical, 65.

106. UCLA sociologist Ronald Edgerton, who conducted a study of Santa Monica's coastline in the early 1970s, declared it "the most diverse... area along the entire beach." Edgerton, Alone Together: Social Order on an Urban Beach (Berkeley: University of California Press, 1979).

107. Santa Monica Evening Outlook, July 5, 1950, 13.

108. See, for instance, LA Sentinel, July 12, 1962, A1.

109. Jefferson, "Leisure's Race, Power and Place," 480.

110. Ebony, April 1965, 109.

111. This topic would require more research. On the Black Surfing Association, see Catherine J. Trujillo, "Tony Corley: Evolution of the Black Surfing Association" at https://www.kcet.org/shows/artbound/tony-corley-evolution-of-the-black-surfingassociation.

112. Marcel Mauss, “Techniques of the Body," Economy and Society 2, no. 1 (1973): 70-88.

113. For a stimulating analysis of how consumer capitalism interacted with, and often coopted, back-to-nature health movements in the twentieth century, see Sarah Shrank, Free and Natural: Nudity and the American Cult of the Body (Philadelphia: University of Pennsylvania Press, 2019).

114. Richard Dyer, The Matter of Images: Essays on Representation (New York: Routledge, 2002), 2.

115. Sarah Schrank, "The Late Capitalist Physique," Modern American History 1, no. 3 (November 2018): 5.

116. Doug Sackman, Orange Empire: California and the Fruits of Eden (Berkeley: University of California Press, 2005); William F. Deverell, Whitewashed Adobe: The Rise of Los Angeles and the Remaking of Its Mexican Past (Berkeley: University of California Press, 2004).

117. Hope Hansen, “Fitness: West Coast," Vogue, August 1989, 166.

\section{ABSTRACTS}

This article explores the origins, whitewashing, and eventual fetishization of the "California look"-a body ideal centered on bronzed skin, bleached hair, and bulging muscles, which gained a prominent place within American visual imagery in the second half of the twentieth century. Rather than solely focusing on representations of California bodies in popular culture, as other 
studies have done, the article locates the origins of the California look in the social history of Los Angeles' beaches and, in particular, their use as sites of corporeal spectacles. Unlike in Europe and the East Coast, where hygienist justifications for seaside recreation endured, from the early twentieth century onwards Southern California beachgoers set medical concerns aside and focused on having fun, and shaping and parading their bodies. In parallel, consumer capitalism, aided by the rise of the beauty, exercise, and diet industries, transformed these local pursuits of health and fitness into a marketable lifestyle and coherent set of body aesthetics. Despite African-American, Asian, and Latino Angelenos' continuing engagement with local beach cultures, national and popular culture representations of such trends systematically erased nonwhite bodies, thereby constructing the California look as a conspicuously white icon.

\section{INDEX}

Keywords: California; beach; bodies; Muscle Beach; Los Angeles; spectacle; surfing; bodybuilding; tanning; health; fitness; leisure; physique

\section{AUTHOR}

\section{ELSA DEVIENNE}

Elsa Devienne is a lecturer in American history at Northumbria University, specializing in the urban, environmental, and gender history of the twentieth-century United States. Her monograph The Sand Rush: An Environmental History of Los Angeles' Beaches is forthcoming from Sorbonne Editions. 